\title{
Article \\ Detection of Carbapenem Resistance of Proteus mirabilis Strains Isolated from Foxes, Raccoons and Minks in China
}

\author{
Penghao Lv ${ }^{1, \dagger}$, Guijuan Hao ${ }^{1, *, \dagger}$, Yanli Cao ${ }^{1}$, Lulu Cui ${ }^{1}$, Guisheng Wang ${ }^{2, *}$ and Shuhong Sun ${ }^{1, * \mathbb{C}}$ \\ 1 Department of Preventive Veterinary Medicine, College of Veterinary Medicine, Shandong Agricultural \\ University, Taian 271018, China; 2019110426@sdau.edu.cn (P.L.); sdaucyl@163.com (Y.C.); \\ 2021010090@sdau.edu.cn (L.C.) \\ 2 Shandong Animal Disease Prevention and Control Center, Taian 261500, China \\ * Correspondence: haogj2020@sdau.edu.cn (G.H.); wangguisheng@shandong.cn (G.W.); \\ sunshuhong@sdau.edu.cn (S.S.); Tel.: +86-182-5202-6546 (G.H.); +86-185-6011-3839 (G.W.); \\ +86-137-0538-9710 (S.S.) \\ + These authors contributed equally to this work.
}

check for updates

Citation: Lv, P.; Hao, G.; Cao, Y.; Cui, L.; Wang, G.; Sun, S. Detection of Carbapenem Resistance of Proteus mirabilis Strains Isolated from Foxes, Raccoons and Minks in China. Biology 2022, 11, 292. https:// doi.org/10.3390/biology11020292

Academic Editors: Chrissoula Voidarou, Athina S. Tzora and Georgios Rozos

Received: 20 December 2021 Accepted: 8 February 2022 Published: 11 February 2022

Publisher's Note: MDPI stays neutral with regard to jurisdictional claims in published maps and institutional affiliations.

Copyright: (C) 2022 by the authors. Licensee MDPI, Basel, Switzerland. This article is an open access article distributed under the terms and conditions of the Creative Commons Attribution (CC BY) license (https:// creativecommons.org/licenses/by/ $4.0 /)$.
Simple Summary: Proteus is found abundantly in soil and water, and it has been known to cause human urinary tract infections and food poisoning. Currently, the opportunistic pathogen Proteus mirabilis (P. mirabilis) is also found to be an emerging threat to animals, such as birds, fish, dogs, etc. In this study, we examined the antibiotic resistance genes and virulence genes of $P$. mirabilis isolates from raccoons, foxes and minks. Among a total of 53 P. mirabilis isolates, the proportion of bacteria resistant to three or more antibiotic classes was up to $73.58 \%$, and the detection rate of carbapenemresistant $P$. mirabilis isolates was up to $71.7 \%$, putting human health at risk. The close evolutionary relationship between $P$. mirabilis isolates from animals and the farm environment suggested that multidrug-resistant $P$. mirabilis from animals could pose a great environmental threat. In addition, the carriage rate of virulence-associated genes was not positively correlated with $P$. mirabilis pathogenicity in a Galleria mellonella model, highlighting the importance of further understanding the virulence of P. mirabilis in future studies.

\begin{abstract}
Proteus mirabilis, an opportunistic pathogen, is found to be an emerging threat to both animals and humans for a variety of infections. However, the characteristics of $P$. mirabilis infections from foxes, raccoons and minks remain unclear. In this context, we identified the antibiotic resistance genes and virulence genes of $P$. mirabilis isolates from foxes, raccoons and minks in China. Most isolates showed resistance to florfenicol $(90.57 \%)$, trimethoprim-sulfamethoxazole $(73.58 \%)$, and imipenem $(71.70 \%)$. A total of $73.58 \%$ of isolates were resistant to antibiotics from at least three or more classes, and were categorized as multi-drug resistant. A total of $33.33 \%$ of the isolates were resistant to antibiotics from seven classes. The most prevalent resistant were sul1 (94.34\%), followed by floR, bla $a_{\mathrm{TEM}}, a a c\left(6^{\prime}\right) \mathrm{Ib}-\mathrm{cr}$ and $b l a_{\mathrm{OXA}-1}$ with the detection rate of $88.68 \%, 83.02 \%, 71.70 \%$ and $60.38 \%$, respectively. Among the $51 \mathrm{P}$. mirabilis isolates that were resistant to beta-lactam antibiotics, all isolates carried at least one beta-lactam gene. In addition, $b l a_{\mathrm{NDM}}$ and $b l a_{\mathrm{OXA}-24}$ genes were firstly reported in carbapenem-resistant $P$. mirabilis isolates from foxes, raccoons and minks. All isolates exhibited the virulence genes $u r e C, z a p A, p m f A$, atf $A$ and $m r p A$. P. mirabilis isolates carrying all detected 10 virulence genes from different animal species showed different lethal abilities in a G. mellonella larvae model. More importantly, the profiles of antibiotic resistance genes of isolates from fur animals and the environment were generally similar, and phylogenetic analysis showed that the P. mirabilis isolates from farm environment samples may have close relatedness with that from animals.
\end{abstract}

Keywords: Proteus mirabilis; antimicrobial resistance; carbapenem resistance; virulence genes 


\section{Introduction}

Proteus mirabilis (P. mirabilis), a Gram-negative bacterium with flagella and fimbriae, is widely found in water, soil, and the intestinal microbiota of animals and humans. As an opportunistic pathogen, P. mirabilis is usually harmless to human health [1]. However, when the body's immunity is weakened, $P$. mirabilis may move to non-intestinal sites and cause serious diseases, such as cystitis, sepsis, peritonitis and meningitis [2,3]. After Escherichia coli (E. coli) and Klebsiella pneumoniae (K. pneumoniae), P. mirabilis is the third most common cause of human urinary tract infections [4]. P. mirabilis is also involved in nosocomial outbreaks in neonates in India [3]. In addition, although Proteus does not belong to the foodborne pathogens, some food poisoning cases associated with P. mirabilis have been reported [5,6]. Gong et al. [6] demonstrated that $P$. mirabilis from humans could induce the symptoms of both vomiting and diarrhea in a mouse model and show high gastrointestinal pathogenicity. Comparative genomic analysis showed that $P$. mirabilis may acquire horizontally from other microbial genomes toxin genes to exert digestion tract infection and toxicity [7]. Currently, the opportunistic pathogen P. mirabilis is found to be an emerging threat to animals. It was reported that $P$. mirabilis could cause large-scale mortality of fish without association with any other pathogens [8]. In addition, P. mirabilis infections have been reported in birds with reproductive failure [9], cattle and fowl with diarrhea $[10,11]$ and dogs with chronic otitis externa [12].

Carbapenems, such as imipenem and meropenem, are bactericidal beta-lactam antimicrobials with proven efficacy in severe infections caused by extended spectrum betalactamases (ESBLs, e.g., TEM, SHV, CTX-M enzymes) producing bacteria [13]. Carbapenem resistance occurs mainly among Gram-negative pathogens such as Enterobacteriaceae, Pseudomonas spp. and Acinetobacter spp., which is mainly due to the production of carbapenemase including some class A beta-lactamases (e.g., KPC, GES), class B metallobeta-lactamases (e.g., NDM, IMP) and class D carbapenemases (e.g., OXA-23, -24, -48, -51, and -58) [14]. KPC-type producing P. mirabilis was identified for the first time in the blood culture of a diabetic patient in the United States in 2008; since then, KPC-producing P. mirabilis isolates have been found in humans in many countries [15-17]. NDM-producing P. mirabilis isolates have been isolated from commercial broilers in slaughterhouses, ducks, wildlife, and hospitalized patients in China [18-21]. Among the carbapenem-hydrolyzing class D beta-lactamases, OXA-48, the most frequently identified in Enterobacterales, has only been very rarely reported in Proteus spp., whereas OXA-23 and OXA-58, exclusively identified in Acinetobacter species, have recently been increasingly identified in P. mirabilis from hospital settings, the community, and cattle feces $[17,22,23]$. In addition, the bla $a_{\mathrm{OXA}-24}$ has also been identified in P. mirabilis isolates from hospital clinical specimens in Algeria [22]. Since $P$. mirabilis is intrinsically resistant to tetracyclines and polymyxins, the emergence of multidrug-resistant, or even extensively drug-resistant $P$. mirabilis isolates carrying carbapenemase genes complicated the clinical treatment of bacterial infections, causing a significant public health concern. Most previous studies were focused on the prevalence of antimicrobial resistance of $P$. mirabilis in human urinary tract infections, and chicken, beef, and pork meat $[19,21,23,24]$. However, there are few reports on the characteristics of P. mirabilis from foxes, raccoons and minks.

The present study aimed to characterize the antibiotic resistance profiles of 53 P. mirabilis isolates obtained from fox, raccoon and mink farms in China, and to compare the genotypic and phenotypic characteristics of antimicrobial resistance and virulence factors in these isolates.

\section{Materials and Methods}

\subsection{Bacterial Isolates and Growth Conditions}

A total of 53 P. mirabilis isolates were used in this study. They were isolated from fox, raccoon, or mink farms in different cities of Shandong Province, China between October 2019 and November 2020 (Table 1). Detailed information on these P. mirabilis isolates is provided in Tables S1 and S2 in the Supplementary Materials. The standard 
Salmonella enterica serovar Enteritidis (S. Enteritidis) strain CVCC3377 was purchased from the China Veterinary Culture Collection Center (Beijing, China). All isolates were streaked on xylose lysine deoxycholate (XLD) agar plates at $37^{\circ} \mathrm{C}$ for $16 \sim 24 \mathrm{~h}$, and then colonies were inoculated in Luria-Bertani (LB) medium. Cultures were grown at $37^{\circ} \mathrm{C}$ and $180 \mathrm{rpm}$ to the stationary phase for subsequent experiments.

Table 1. Fifty-three isolates of P. mirabilis from fox, mink and raccoon farms used in this study.

\begin{tabular}{cccc}
\hline \multirow{2}{*}{ Isolates } & $\begin{array}{c}\text { Year of } \\
\text { Isolation }\end{array}$ & \multicolumn{2}{c}{ Source } \\
\cline { 3 - 4 } & 2019 & 12 isolates from fox feces & $\begin{array}{c}\text { A isolates from soil samples } \\
1 \text { isolate from feed sample }\end{array}$ \\
\hline F1-F22 & 2019 & 15 isolates from raccoon feces & 3 isolates from soil samples \\
\hline R1-R18 & 2020 & $\begin{array}{c}\text { 2 isolates from mink feces, } \\
\text { 3 isolates from carcass samples, } \\
\text { 1 isolate from throat samples, }\end{array}$ & 1 isolate from feed sample \\
\hline & & & \\
\hline
\end{tabular}

${ }^{1}$ The soil samples were collected from the soil within $1 \mathrm{~m}$ around the animal cage, and the feed samples were collected from leftover animal feed in the feed trough. F1-F22 are from one fox farm, R1-R18 are from one raccoon farm and M1-M13 are from two mink farms in China.

\subsection{Antimicrobial Susceptibility Testing}

The CLSI disk diffusion method was used in this study to examine antibiotic resistance of $P$. mirabilis isolates to 11 antibiotics from 7 classes, including cefepime (FEP, $30 \mu \mathrm{g})$, cefotaxime (CTX, $30 \mu \mathrm{g})$, ceftazidime (CAZ, $30 \mu \mathrm{g})$, gentamicin (GM, $10 \mu \mathrm{g})$, imipenem (IPM, $10 \mu \mathrm{g}$ ), ampicillin (AMP, $10 \mu \mathrm{g}$ ), streptomycin (STR, $10 \mu \mathrm{g}$ ), ofloxacin (OFX, $5 \mu \mathrm{g}$ ), enrofloxacin (ENR, $15 \mu \mathrm{g}$ ), and trimethoprim-sulfamethoxazole (SXT, $25 \mu \mathrm{g})$. In brief, $0.5 \mathrm{McF}$ arland P. mirabilis inoculum from liquid culture was spread onto Mueller-Hinton agar plates (Hopebiol), and the antibiotic discs were dispensed on the agar. Plates were incubated at $35{ }^{\circ} \mathrm{C}$ air incubator for 16 to $18 \mathrm{~h}$. E. coli (ATCC 25922) was used as a quality control strain. The results were interpreted based on the Clinical and Laboratory Standards Institute (CLSI) M100-S27 guideline and CLSI Supplement VET01S [25,26]. The broth microdilution method was used for the determination of the minimum inhibitory concentrations (MICs) of P. mirabilis isolates to florfenicol (FFC). P. mirabilis isolates resistant to one or more antibiotics in three or more antibiotic classes were defined as multidrugresistant (MDR).

\subsection{Detection of Antimicrobial Resistance Genes}

A total of 31 antimicrobial resistance genes in 5 categories, beta-lactam resistance genes $\left(b l a_{\mathrm{SHV}}, b l a_{\mathrm{OXA}-1}, b l a_{\mathrm{OXA}-23}, b l a_{\mathrm{OXA}-24}, b l a_{\mathrm{OXA}-58}, b l a_{\mathrm{OXA}-48}, b l a_{\mathrm{CTX}-\mathrm{M}}, b l a_{\mathrm{TEM}}, b l a_{\mathrm{PSE}}\right.$, bla $\left.a_{\mathrm{KPC}}, b l a_{\mathrm{NDM}}, b l a_{\mathrm{IMP}}, b l a_{\mathrm{VIM}}\right)$ [27-31], aminoglycoside resistance genes (aaC1, aaC2, aaC3, aad $A, a a d B, a p h A 6$, aac $\left.\left(6^{\prime}\right)-I b-c r\right)$ [32-35], quinolone resistance genes ( $q n r A, q n r B, q n r C, q n r S$, oqxA, aac $\left.\left(6^{\prime}\right)-I b-c r\right)[27,35]$, folate pathway antagonist resistance genes (sul1, sul2, sul3) and phenicol resistance genes $(f l o R, c m l A)$ were identified by PCR with the primers in Table A1 as previously described [27,36-38]. Bacterial DNA samples were prepared by the boiling method with a modification [39]. Briefly, approximately $10^{8} \mathrm{CFU} / \mathrm{mL}$ cells in $\mathrm{ddH}_{2} \mathrm{O}$ were boiled at $100{ }^{\circ} \mathrm{C}$ for $10 \mathrm{~min}$ in a water bath, then cells were centrifuged for five minutes at $1000 \mathrm{rpm}$ and the supernatants were used for the PCR directly. The PCR was carried out in a $25 \mu \mathrm{L}$ reaction mixture containing $12.5 \mu \mathrm{L}$ of $2 \times$ Taq Master Mix (Vazyme, Nanjing, China), $1 \mu \mathrm{L}$ of each primer (10 pmol), $9.5 \mu \mathrm{L}$ of $\mathrm{ddH}_{2} \mathrm{O}$ and $1 \mu \mathrm{L}$ of DNA template using a T100TM Thermal Cycler (BIO-RAD, Hercules, CA, USA). $\mathrm{ddH}_{2} \mathrm{O}$ was used as a negative control. PCR products were analyzed by $1 \%$ agarose gel electrophoresis at $100 \mathrm{~V}$ for $20 \mathrm{~min}$ and imaged. 


\subsection{Detection of Virulence Genes}

The virulence genes $m r p A, p m f A$, atf $A$, atfC (fimbriae), ureC (urease), zapA (protease), $u c a A$ (adhesin), $r s b A$ (migration), $r s m A$ (repressor of secondary metabolites) and $h m p A$ (hemolysin) of $P$. mirabilis were identified with the previous primers and described PCR reaction system (Appendix A Table A2) [11,40], the bacterial DNA and PCR reaction mixture were prepared as described above.

\subsection{Infection of Galleria Mellonella Larvae}

In this study, the larvae of the Galleria mellonella (G. mellonella) wax moth was used to assess the pathogenicity of $P$. mirabilis as described previously with modifications [41]. Stationary bacterial cells were washed with PBS and then diluted in PBS to an optical density at $\mathrm{OD}_{600}$ of 1 , which corresponds to approximately $1 \times 10^{9} \mathrm{CFU} / \mathrm{mL}$. For $50 \%$ lethal dose $\left(\mathrm{LD}_{50}\right)$ experiments, a series of 10 -fold serial dilutions containing $10^{4}$ to $10^{8} \mathrm{CFU}$ in PBS were injected into G. mellonella larvae. After surface disinfection using 70\% ethanol, a Microliter Syringe (Shanghai Gaoge, Shanghai, China) was used to inject $10 \mu \mathrm{L}$ aliquots of the inoculum into the hemocoel of each larvae via the last left proleg [42]. A group of 10 larvae were injected with $10 \mu \mathrm{L}$ of PBS in parallel to ensure that death was not due to injection trauma. Larvae were placed in $9.2 \mathrm{~cm}$ Petri dishes and kept at $37^{\circ} \mathrm{C}$ in the dark. Insects were considered dead when they displayed no movement in response to touch. The number of dead larvae was scored at 6, 12, and $24 \mathrm{~h}$ post-infection. For each strain, at least three independent experiments were performed, and $\mathrm{LD}_{50}$ s were calculated according to the formula of Käber [43].

\subsection{Determination of In Vivo Bacterial Loads}

Each group containing 15 larvae was infected with approximately $1 \times 10^{3} \mathrm{CFU}$ per larva of P. mirabilis isolates (F13, R8 and M1) or S. Enteritidis CVCC3377, respectively. Three insects in each group were collected at different post-infection time points $(6 \mathrm{~h}$ and death time within $12 \mathrm{~h}$ ) to determine bacterial loads. After surface disinfection with 70\% ethanol, larvae were homogenized in $2 \mathrm{~mL}$ of PBS by use of a High-Speed KZ-II Basic Homogenizer (Servicebio, Wuhan, China). Serial dilutions of the homogenates in PBS were plated on XLD agar, and colonies were counted after incubation at $37^{\circ} \mathrm{C}$ for $24 \mathrm{~h}$. Three independent experiments were performed.

\subsection{Phylogenetic Tree Analysis}

The $16 \mathrm{~S}$ ribosomal RNA (16S rRNA) gene sequences of 53 P. mirabilis isolates were amplified with primers 27F and 1492R [44]. The PCR products were sequenced and identified using BLAST algorithms against the NCBI databases. A total of 8 representative P. mirabilis isolates from different isolation sources (chicken, snake, milk, etc.) were selected to construct a phylogenetic tree. Multiple alignments of the $16 \mathrm{~S}$ rRNA gene sequences were conducted with the ClustalW algorithm, and phylogenetic trees were constructed by MEGA 7.0 software (Pennsylvania State University, College Town, PA, USA) using the Neighbor-Joining method [45].

\subsection{Data Availability}

The partial $16 \mathrm{~S}$ rRNA gene sequences of $53 \mathrm{P}$. mirabilis isolates were all deposited in the NCBI database under the GenBank accession numbers OL629182-OL629203 (F1-F22), OL629209-OL629226 (R1-R18) and OL629229-OL629241 (M1-M13).

\section{Results}

\subsection{Antimicrobial Susceptibility of P. mirabilis Isolates}

As shown in Table 2, all isolates were sensitive to cefepime $(53 / 53,100 \%)$, and most isolates were sensitive to ceftazidime $(48 / 53,90.57 \%)$ and ofloxacin $(44 / 53,83.02 \%)$. Most isolates were resistant to florfenicol (48/53, 90.57\%), trimethoprim-sulfamethoxazole $(39 / 53,73.58 \%)$, imipenem $(38 / 53,71.70 \%)$, enrofloxacin $(34 / 53,64.15 \%)$, ampicillin $(33 / 53$, 
$63.46 \%)$, streptomycin $(32 / 53,60.38 \%)$, gentamicin $(27 / 53,50.94 \%)$, and cefotaxime $(26 / 53$, $49.06 \%)$. We found that the proportion of MDR isolates was 73.58\% (39/53). Among the 39 MDR P. mirabilis isolates, isolates resistant to seven classes of antibiotics accounted for the highest proportion $(33.33 \%, 13 / 39)$ (Figure 1), of which nine were from raccoons and four were from foxes.

Table 2. The sensitivity of 53 P. mirabilis isolates isolated from fox, raccoon and mink farms to 11 antibiotics.

\begin{tabular}{ccccc}
\hline \multirow{2}{*}{ Antibiotic Classes } & \multirow{2}{*}{ Antibiotics } & \multicolumn{3}{c}{ Number of Isolates } \\
\cline { 3 - 4 } & & Resistant & Intermediate & Susceptible \\
\hline \multirow{2}{*}{ Cephems } & Cefepime (FEP) & 0 & $1(1.89 \%)$ & $52(98.11 \%)$ \\
& Cefotaxime (CTX) & $26(49.06 \%)$ & $8(15.10 \%)$ & $19(35.85 \%)$ \\
Penicillins & Ceftazidime (CAZ) & $5(9.43 \%)$ & 0 & $48(90.57 \%)$ \\
Carbapenems & Ampicillin (AMP) & $33(63.46 \%)$ & $11(20.75 \%)$ & $9(16.98 \%)$ \\
Aminoglycosides & Imipenem (IPM) & $38(71.70 \%)$ & 0 & $15(28.30 \%)$ \\
& Gentamicin (GM) & $27(50.94 \%)$ & $1(1.89 \%)$ & $25(47.17 \%)$ \\
Quinolones & Streptomycin (STR) & $32(60.38 \%)$ & $13(24.53 \%)$ & $8(15.10 \%)$ \\
& Ofloxacin (OFX) & $9(16.98 \%)$ & $8(15.09 \%)$ & $36(67.92 \%)$ \\
Folate pathway & Enrofloxacin (ENR) & $34(64.15 \%)$ & $14(26.42 \%)$ & $5(9.43 \%)$ \\
antagonists & Trimethoprim- & & & $1(1.89 \%)$ \\
Phenicols & sulfamethoxazole & $39(73.58 \%)$ & & $13(24.53 \%)$ \\
(SXT) & & & \\
& Florfenicol (FFC) & $48(90.57 \%)$ & $4(7.55 \%)$ & $1(1.89 \%)$ \\
\hline
\end{tabular}

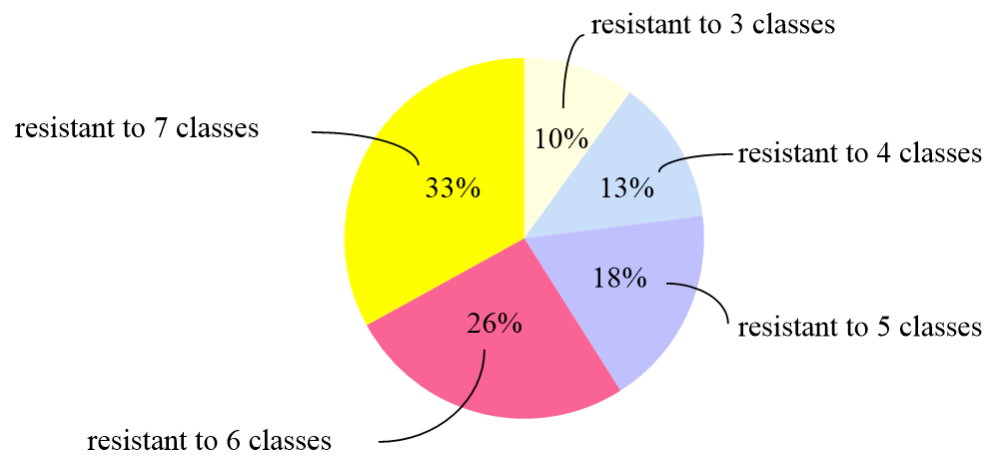

Figure 1. The proportion of MDR P. mirabilis isolates to different classes of antibiotics used in this study.

The isolates from the fox farm had generally higher resistance rate than the isolates from raccoon and mink farms (Figure 2). Among the P. mirabilis isolates from raccoons and foxes, the significantly different resistance rates to antibiotics were as follows, respectively: to CTX, $40.9 \%$ and $94.4 \%(p<0.001)$; to AMP, $54.5 \%$ and $88.9 \%(p<0.05)$; to GM, $40.9 \%$ and $83.3 \%(p<0.01)$. Meanwhile, by comparing the antibiotic resistance rates between the isolates from minks and foxes, the difference was mainly in AMP $(p<0.01)$, IMP $(p<0.01)$, GM $(p<0.001)$ and STR $(p<0.01)$. The resistant rates of $P$. mirabilis isolates from raccoons and foxes to CTX, CAZ and OFX were $9.1 \% \sim 94 \%$, but no isolate from mink showed resistance to the above three antibiotics. No difference was found in ENR, SXT and FFC resistance among the isolates from the above three kinds of animals. 


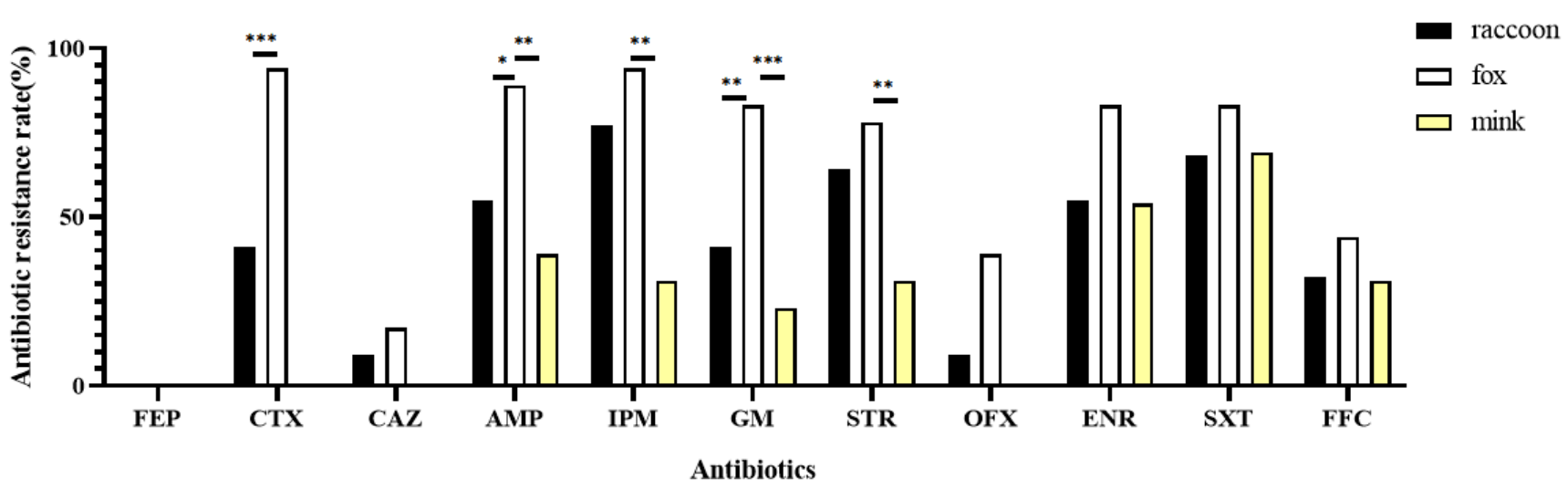

Figure 2. Comparison of the antibiotic resistance rates of $P$. mirabilis isolates between raccoons, foxes and minks. The difference was analyzed by chi-squared test. ${ }^{*} p<0.05 ;{ }^{* *} p<0.01$; ${ }^{* * *} p<0.001$.

\subsection{Antimicrobial Resistance Genes of P. mirabilis}

The most frequently detected antimicrobial resistance gene was sul1 $(94.34 \%, 50 / 53)$, followed by floR, bla $a_{\mathrm{TEM}}, a a c\left(6^{\prime}\right) I b-c r$ and $b l a_{\mathrm{OXA}-1}$, with the detection rate of $88.68 \%(47 / 53)$, $83.02 \%$ (44/53), $71.70 \%(38 / 53)$ and $60.38 \%$ (32/53), respectively (Table 3). Among the 14 beta-lactamase genes detected, $b l a_{\mathrm{TEM}}$ was the most prevalent beta-lactamase gene $(83.02 \%)$, followed by bla $a_{\mathrm{OXA}-1}(60.38 \%)$, bla $a_{\mathrm{CTX}-\mathrm{M}}(32.08 \%)$, bla $_{\mathrm{PSE}}(24.53 \%)$, bla $_{\mathrm{OXA}-24}$ $(15.09 \%)$, and bla $_{\mathrm{NDM}}(13.21 \%)$. Among the $51 \mathrm{P}$. mirabilis isolates that were resistant to beta-lactam antibiotics, all isolates carried at least one related drug resistance gene, of which most isolates $(23.5 \%)$ carried only the $b l a_{\text {TEM }}$ gene, followed by isolates harboring bla $a_{\mathrm{TEM}}, b l a_{\mathrm{CTX}-\mathrm{M}}$ and $b l a_{\mathrm{OXA}-1}(19.6 \%)$ and isolates harboring both $b l a_{\mathrm{TEM}}$ and $b l a_{\mathrm{OXA}-1}$ $(9.8 \%)$ (Figure 3A). For quinolone resistance genes, the detection rate of $a a c\left(6^{\prime}\right)-I b-c r, q n r A$, $q n r B$ and $q n r C$ was $71.70 \%, 5.66 \%, 22.64 \%$ and $15.09 \%$, respectively, but $q n r S$ and $o q x A$ were not detected. Most isolates carry the folate pathway antagonist resistance gene sul1 $(94.34 \%)$, followed by sul3 $(54.72 \%)$ and sul2 $(11.32 \%)$, respectively. Among phenicol resistance genes, the detection rate of floR was up to $88.68 \%$, followed by $\mathrm{cmlA}(5.66 \%)$. In addition, four aminoglycoside resistance genes $(a a C 2, a a d A$, aadB and $a p h A 6)$ were detected, accounting for $9.43 \%, 83.02 \%, 13.23 \%$ and $11.32 \%$, respectively.

Table 3. Detection rates of drug resistance genes of 53 P. mirabilis isolates used in this study.

\begin{tabular}{|c|c|c|c|c|c|}
\hline \multirow{2}{*}{ Name } & \multirow{2}{*}{ Gene } & \multicolumn{4}{|c|}{ Detection Rate } \\
\hline & & Raccoon & Fox & Mink & $>$ Total \\
\hline \multirow{13}{*}{ Beta-lactams } & $b l a_{\mathrm{TEM}}$ & $33.96 \%$ & $41.51 \%$ & $7.55 \%$ & $83.02 \%$ \\
\hline & bla $_{\mathrm{SHV}}$ & 0 & 0 & 0 & 0 \\
\hline & bla $a_{\mathrm{PSE}}$ & 0 & 0 & $24.53 \%$ & $24.53 \%$ \\
\hline & $b l a_{\mathrm{OXA}-1}$ & $32.08 \%$ & $9.43 \%$ & $18.87 \%$ & $60.38 \%$ \\
\hline & $b l a_{\text {OXA-23 }}$ & 0 & 0 & 0 & 0 \\
\hline & $b l a_{\text {OXA-24 }}$ & 0 & $3.78 \%$ & $11.32 \%$ & $15.09 \%$ \\
\hline & $b l a_{\text {OXA }-58}$ & 0 & 0 & 0 & 0 \\
\hline & $b l a_{\mathrm{OXA}-48}$ & 0 & 0 & 0 & 0 \\
\hline & $b l a_{\mathrm{CTX}-\mathrm{M}}$ & $18.87 \%$ & $13.21 \%$ & 0 & $32.08 \%$ \\
\hline & $b l a_{\mathrm{KPC}}$ & 0 & 0 & 0 & 0 \\
\hline & $b l a_{\mathrm{NDM}}$ & $11.32 \%$ & $1.89 \%$ & 0 & $13.21 \%$ \\
\hline & $b l a_{\mathrm{IMP}}$ & 0 & 0 & 0 & 0 \\
\hline & $b l a_{\mathrm{VIM}}$ & 0 & 0 & 0 & 0 \\
\hline \multirow{6}{*}{ Aminoglycosides } & $a a C 1$ & 0 & 0 & 0 & 0 \\
\hline & $a a C 2$ & 0 & 0 & $9.43 \%$ & $9.43 \%$ \\
\hline & $a a C 3$ & 0 & 0 & 0 & 0 \\
\hline & aadA & $28.30 \%$ & $32.08 \%$ & $22.64 \%$ & $83.02 \%$ \\
\hline & $a a d B$ & $7.56 \%$ & $1.89 \%$ & $3.78 \%$ & $13.23 \%$ \\
\hline & $a p h A 6$ & 0 & $5.66 \%$ & $5.66 \%$ & $11.32 \%$ \\
\hline
\end{tabular}


Table 3. Cont.

\begin{tabular}{|c|c|c|c|c|c|}
\hline \multirow{2}{*}{ Name } & \multirow{2}{*}{ Gene } & \multicolumn{4}{|c|}{ Detection Rate } \\
\hline & & Raccoon & Fox & Mink & $>$ Total \\
\hline \multirow{6}{*}{ Quinolones } & $a a c\left(6^{\prime}\right)-I b-c r$ & $32.08 \%$ & $15.09 \%$ & $24.53 \%$ & $71.70 \%$ \\
\hline & $q n r A$ & $3.78 \%$ & $1.89 \%$ & 0 & $5.66 \%$ \\
\hline & $q n r B$ & 0 & 0 & $22.64 \%$ & $22.64 \%$ \\
\hline & $q n r C$ & $9.43 \%$ & $5.66 \%$ & 0 & $15.09 \%$ \\
\hline & $q n r S$ & 0 & 0 & 0 & 0 \\
\hline & $o q x A$ & 0 & 0 & 0 & 0 \\
\hline \multirow{3}{*}{$\begin{array}{l}\text { Folate pathway } \\
\text { antagonists }\end{array}$} & sul1 & $33.96 \%$ & $41.51 \%$ & $18.87 \%$ & $94.34 \%$ \\
\hline & sul2 & 0 & 0 & $11.32 \%$ & $11.32 \%$ \\
\hline & sul3 & $32.08 \%$ & $20.75 \%$ & $1.89 \%$ & $54.72 \%$ \\
\hline \multirow{2}{*}{ Phenicols } & $\mathrm{cmlA}$ & 0 & 0 & $5.66 \%$ & $5.66 \%$ \\
\hline & floR & $33.96 \%$ & $41.51 \%$ & $13.21 \%$ & $88.68 \%$ \\
\hline
\end{tabular}

A
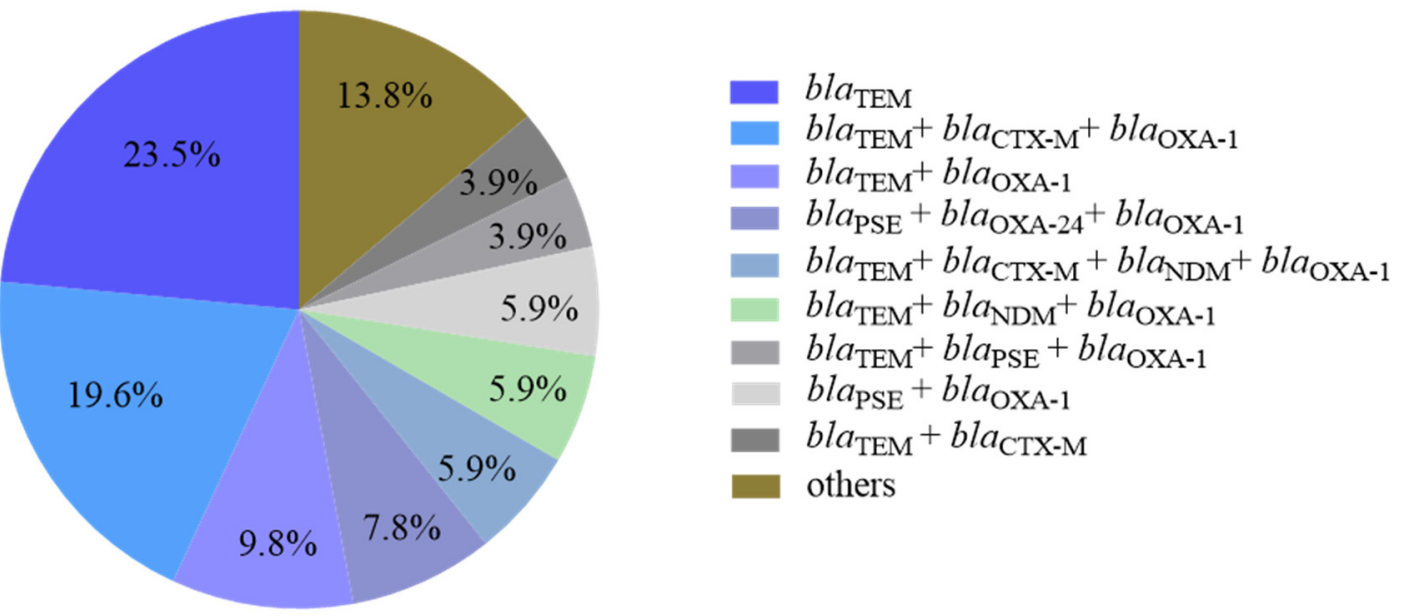

$\mathrm{B}$ Animal samples ए Farm environment samples

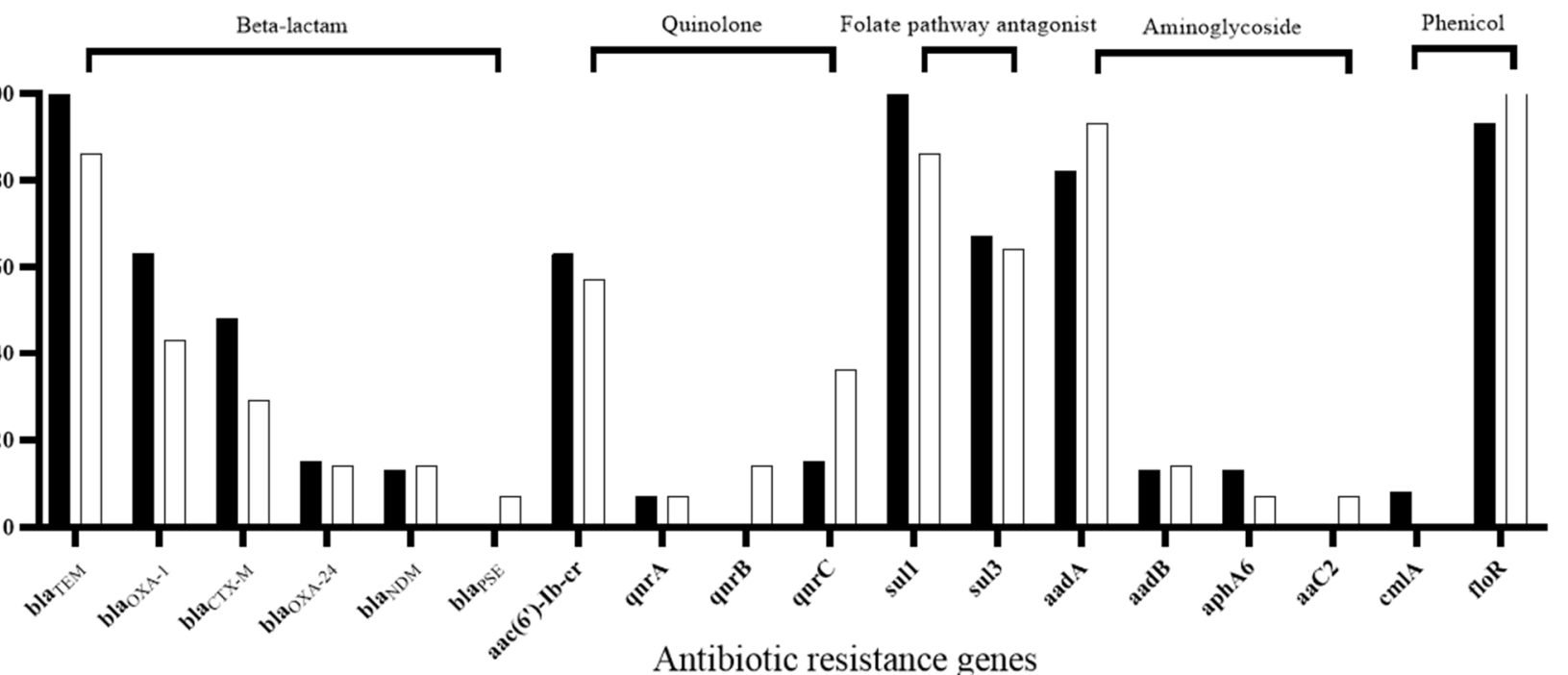

Figure 3. (A) Beta-lactam antibiotics resistance genes among the 53 P. mirabilis isolates. (B) Comparison of the detection rate of resistance genes in P. mirabilis isolates from animal samples and farm environment samples. 
By comparing the antimicrobial resistance genes from fox, raccoon and mink farms, we found that gene $b l a_{\mathrm{TEM}}, b l a_{\mathrm{OXA}-1}, a a c\left(6^{\prime}\right)-I b-c r, s u l 1$, and floR were common. However, $b l a_{\mathrm{CTX}-\mathrm{M}}, q n r A$ and $q n r C$ were only detected in $P$. mirabilis isolates from raccoons and foxes. In addition, the genes $b l a_{\mathrm{PSE}}, q n r B, a a C 2, s u l 2$ and $c m l A$ were specific for the isolates from minks. These results show the diversity of antibiotic resistance genes among different farms.

We also compared the detection rate of antibiotic resistance genes between samples from animals (feces, throat, anal and carcass) and the farm environment (feed and soil), and found that the detection rates of antibiotic resistance genes were generally similar (Figure 3B). The proportions of bla $a_{\mathrm{TEM}}$-positive, sull-positive and floR-positive isolates from animal samples and farm environment samples were all above $85 \%$. Although $b l a_{\mathrm{TEM}}$,

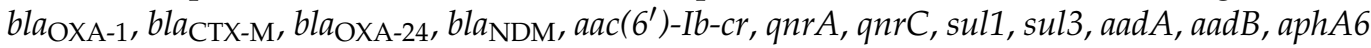
and floR genes were prevalent in both animal samples and farm environment samples, no significant difference $(p>0.05)$ was found between the positive rates of the two groups of samples.

\subsection{Virulence Genes of P. mirabilis Isolates}

Among the 10 virulence genes, ure $C$, zapA, $p m f A$, atf $A$ and $m r p A$ genes were all detected among 53 P. mirabilis isolates, followed by both atfC and $h m p A$ genes, both with a detection rate of $98.11 \%, r s m A$ at $94.34 \%, r s b A$ at $71.70 \%$ and $u c a A$ at $45.28 \%$ (Table 4 ).

Table 4. Detection rate of 10 virulence genes of $P$. mirabilis isolates from different farms.

\begin{tabular}{|c|c|c|c|c|}
\hline \multirow{2}{*}{ Gene } & Fox & Raccoon & Mink & Total \\
\hline & $(n=22)$ & $(n=18)$ & $(n=13)$ & $(n=53)$ \\
\hline ureC & $100 \%$ & $100 \%$ & $100 \%$ & $100 \%$ \\
\hline$z a p A$ & $100 \%$ & $100 \%$ & $100 \%$ & $100 \%$ \\
\hline$p m f A$ & $100 \%$ & $100 \%$ & $100 \%$ & $100 \%$ \\
\hline$m r p A$ & $100 \%$ & $100 \%$ & $100 \%$ & $100 \%$ \\
\hline atfC & $100 \%$ & $94.44 \%$ & $100 \%$ & $98.11 \%$ \\
\hline $\operatorname{atf} A$ & $100 \%$ & $100 \%$ & $100 \%$ & $100 \%$ \\
\hline ucaA & $45.45 \%$ & $33.33 \%$ & $61.54 \%$ & $45.28 \%$ \\
\hline$r s b A$ & $68.18 \%$ & $61.11 \%$ & $92.31 \%$ & $71.70 \%$ \\
\hline rsmA & $95.45 \%$ & $100 \%$ & $84.62 \%$ & $94.34 \%$ \\
\hline hmpA & $95.45 \%$ & $100 \%$ & $100 \%$ & $98.11 \%$ \\
\hline
\end{tabular}

\subsection{Pathogenicity of P. mirabilis Isolates}

\subsubsection{Pathogenicity Comparison of P. mirabilis Isolates from Different Animal Sources}

To determine the pathogenicity of $P$. mirabilis isolates from different animal sources, three $P$. mirabilis isolates (F13, R8 and M1) that carry all detected 10 virulence genes were selected. The $\mathrm{LD}_{50}$ of $P$. mirabilis F13, R8, and M1 in G. mellonella larvae model were $2.5 \times 10^{4} \mathrm{CFU} /$ larvae, $2.0 \times 10^{4} \mathrm{CFU} /$ larvae and $3.9 \times 10^{5} \mathrm{CFU} /$ larvae at $6 \mathrm{~h}$ post infection, respectively (Table 5). The results indicate that the virulence of $P$. mirabilis $\mathrm{M} 1$ from minks seemed to be weaker than F13 from foxes and R8 from raccoons. 
Table 5. The $\mathrm{LD}_{50} \mathrm{~s}$ of three P. mirabilis isolates from different animal species in G. mellonella larvae model.

\begin{tabular}{|c|c|c|c|c|c|}
\hline \multirow{2}{*}{ Isolates } & \multirow{2}{*}{$\begin{array}{l}\text { Bacteria Dose } \\
\text { (CFU/Larvae) }\end{array}$} & \multicolumn{3}{|c|}{ Dead } & \multirow{2}{*}{$\begin{array}{c}\mathrm{LD}_{50}(6 \mathrm{~h}) \\
\text { (CFU/Larvae) }\end{array}$} \\
\hline & & $6 \mathrm{~h}$ & $12 \mathrm{~h}$ & $24 \mathrm{~h}$ & \\
\hline \multirow{5}{*}{ F13 } & $1 \times 10^{6}$ & 9 & 10 & 10 & \multirow{5}{*}{$2.5 \times 10^{4}$} \\
\hline & $1 \times 10^{5}$ & 6 & 10 & 10 & \\
\hline & $1 \times 10^{4}$ & 6 & 10 & 10 & \\
\hline & $1 \times 10^{3}$ & 0 & 10 & 10 & \\
\hline & $1 \times 10^{2}$ & 0 & 10 & 10 & \\
\hline \multirow{5}{*}{ R8 } & $1 \times 10^{6}$ & 9 & 10 & 10 & \multirow{5}{*}{$2.0 \times 10^{4}$} \\
\hline & $1 \times 10^{5}$ & 10 & 10 & 10 & \\
\hline & $1 \times 10^{4}$ & 3 & 10 & 10 & \\
\hline & $1 \times 10^{3}$ & 0 & 10 & 10 & \\
\hline & $1 \times 10^{2}$ & 0 & 10 & 10 & \\
\hline \multirow{5}{*}{ M1 } & $1 \times 10^{6}$ & 9 & 10 & 10 & \multirow{5}{*}{$3.9 \times 10^{5}$} \\
\hline & $1 \times 10^{5}$ & 0 & 10 & 10 & \\
\hline & $1 \times 10^{4}$ & 0 & 10 & 10 & \\
\hline & $1 \times 10^{3}$ & 0 & 9 & 10 & \\
\hline & $1 \times 10^{2}$ & 0 & 6 & 10 & \\
\hline
\end{tabular}

To further determine whether G. mellonella mortality is associated with the growth of bacteria in infected larvae, larvae were injected with $10^{3} \mathrm{CFU}$ of $P$. mirabilis. As shown in Figure 4A, infection of G. mellonella with the F13, R8, and M1 strain resulted in a $10^{4} \sim 10^{5}$-fold increase in CFU at $6 \mathrm{~h}$ post infection, which was followed by further increases in the bacterial numbers of dead larvae within $12 \mathrm{~h}$ post infection. These results are similar to that of larvae infected with pathogenic $S$. Enteritidis CVCC3377, which caused a remarkable increase in bacterial numbers in G. mellonella over time. At $12 \mathrm{~h}$ post infection, larvae in P. mirabilis infection group were all dead, whereas $60 \%$ larvae survived in the $S$. Enteritidis infection group (Figure 4B). The results demonstrate that $P$. mirabilis isolates from fox, mink and raccoon farms could replicate rapidly in vivo and displayed high virulence in G. mellonella larvae model.

A

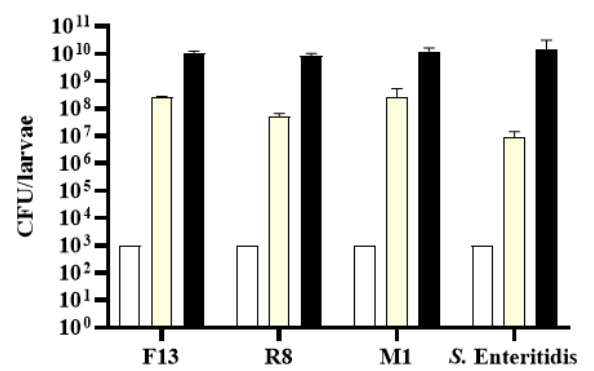

$\mathrm{B}$

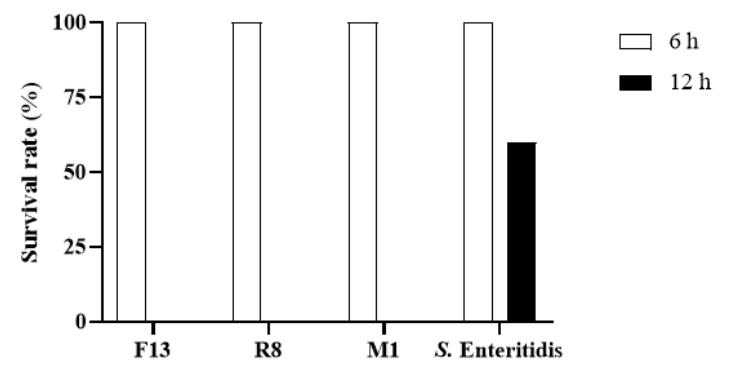

Figure 4. Comparison of pathogenicity between three P. mirabilis isolates from different animal sources and S. Enteritidis. (A) The bacterial loads in larvae infected with P. mirabilis and S. Enteritidis. (B) Survival rate in larvae infected with P. mirabilis and S. Enteritidis at 6 and $12 \mathrm{~h}$ post infection. Each group was infected with approximately $1 \times 10^{3} \mathrm{CFU}$ per larva of $P$. mirabilis isolates (F13, R8 and M1) or S. Enteritidis CVCC 3377, respectively. Three infected larvae from each group were pooled and homogenized, and the numbers of CFU were determined by plating. The survival rates in each group were calculated at 6 and $12 \mathrm{~h}$ post-infection. $n=15$.

\subsubsection{Pathogenicity of P. mirabilis Isolates with Different Virulence Genes}

To evaluate the effect of virulence genes on the pathogenicity of $P$. mirabilis isolates, three isolates, which were all isolated from fox feces but with different virulence genes, were selected to compare their virulence in a G. mellonella model. As shown in Table 6, the $\mathrm{LD}_{50}$ of 
$\mathrm{F} 2, \mathrm{~F} 3$, and F6 isolates at $6 \mathrm{~h}$ post infection was $2.0 \times 10^{4} \mathrm{CFU} /$ larvae, $7.9 \times 10^{3} \mathrm{CFU} /$ larvae and $4.0 \times 10^{3} \mathrm{CFU} /$ larvae, respectively. Although strain F2 carried all detected virulence genes, its $\mathrm{LD}_{50}$ was 2.53- and 5-fold higher than that of strain F3 lacking $u c a A, r s b A$ and $r s m A$, and strain F6 lacking $u c a A$. The results indicate that the carriage rate of virulence-associated genes was not positively correlated with P. mirabilis pathogenicity in G. mellonella larvae.

Table 6. Pathogenicity of P. mirabilis isolates with different virulence genes from foxes in G. mellonella larvae.

\begin{tabular}{|c|c|c|c|c|c|c|c|c|}
\hline \multirow{2}{*}{ Tested Strain } & \multicolumn{3}{|c|}{ Virulence Gene } & \multirow{2}{*}{$\begin{array}{l}\text { Bacteria Dose } \\
\text { (CFU/Larvae) }\end{array}$} & \multicolumn{3}{|c|}{ Dead } & \multirow{2}{*}{$\begin{array}{l}\mathrm{LD}_{50}(6 \mathrm{~h}) \\
\text { (CFU/Larvae) }\end{array}$} \\
\hline & $u c a A$ & $r s b A$ & $r s m A$ & & $6 \mathrm{~h}$ & $12 \mathrm{~h}$ & $24 \mathrm{~h}$ & \\
\hline \multirow{5}{*}{$\mathrm{F} 2$} & \multirow{5}{*}{+} & \multirow{5}{*}{+} & \multirow{5}{*}{+} & $1 \times 10^{6}$ & 10 & 10 & 10 & \multirow{5}{*}{$2.0 \times 10^{4}$} \\
\hline & & & & $1 \times 10^{5}$ & 7 & 10 & 10 & \\
\hline & & & & $1 \times 10^{4}$ & 5 & 10 & 10 & \\
\hline & & & & $1 \times 10^{3}$ & 0 & 1 & 3 & \\
\hline & & & & $1 \times 10^{2}$ & 0 & 0 & 2 & \\
\hline \multirow{5}{*}{ F3 } & \multirow{5}{*}{-} & \multirow{5}{*}{-} & \multirow{5}{*}{ - } & $1 \times 10^{6}$ & 10 & 10 & 10 & \multirow{5}{*}{$7.9 \times 10^{3}$} \\
\hline & & & & $1 \times 10^{5}$ & 9 & 10 & 10 & \\
\hline & & & & $1 \times 10^{4}$ & 7 & 10 & 10 & \\
\hline & & & & $1 \times 10^{3}$ & 0 & 10 & 10 & \\
\hline & & & & $1 \times 10^{2}$ & 0 & 8 & 10 & \\
\hline \multirow{5}{*}{ F6 } & \multirow{5}{*}{-} & \multirow{5}{*}{+} & \multirow{5}{*}{+} & $1 \times 10^{6}$ & 10 & 10 & 10 & \multirow{5}{*}{$4.0 \times 10^{3}$} \\
\hline & & & & $1 \times 10^{5}$ & 10 & 10 & 10 & \\
\hline & & & & $1 \times 10^{4}$ & 9 & 10 & 10 & \\
\hline & & & & $1 \times 10^{3}$ & 0 & 10 & 10 & \\
\hline & & & & $1 \times 10^{2}$ & 0 & 10 & 10 & \\
\hline
\end{tabular}

\subsection{Phylogenetic Analysis of P. mirabilis Isolates}

The 53 P. mirabilis isolates and the selected eight representative isolates of $P$. mirabilis $16 \mathrm{~S}$ rRNA gene sequences obtained on NCBI were used to perform phylogenetic analysis to understand the evolutionary relationship among the P. mirabilis isolates (Figure 5). The results show that the sequence similarity between the 53 isolates and eight representative bacteria was $99.5 \sim 99.9 \%$, but the P. mirabilis isolates from fur farms have far lower relatedness with the representative $P$. mirabilis isolates from shrimp, chick, mastitic milk, etc. The 22 P. mirabilis isolates from foxes and 18 isolates from raccoons were co-clustered into three branches, but the 13 P. mirabilis isolates from minks formed many clades in the evolutionary phylogeny, indicating there may be multiple origins of $P$. mirabilis isolates from minks. Moreover, the isolates from animal samples and farm environment samples were distributed across different branches. This pattern suggested that the isolates from farm environment samples had close relatedness with those from animal samples. 


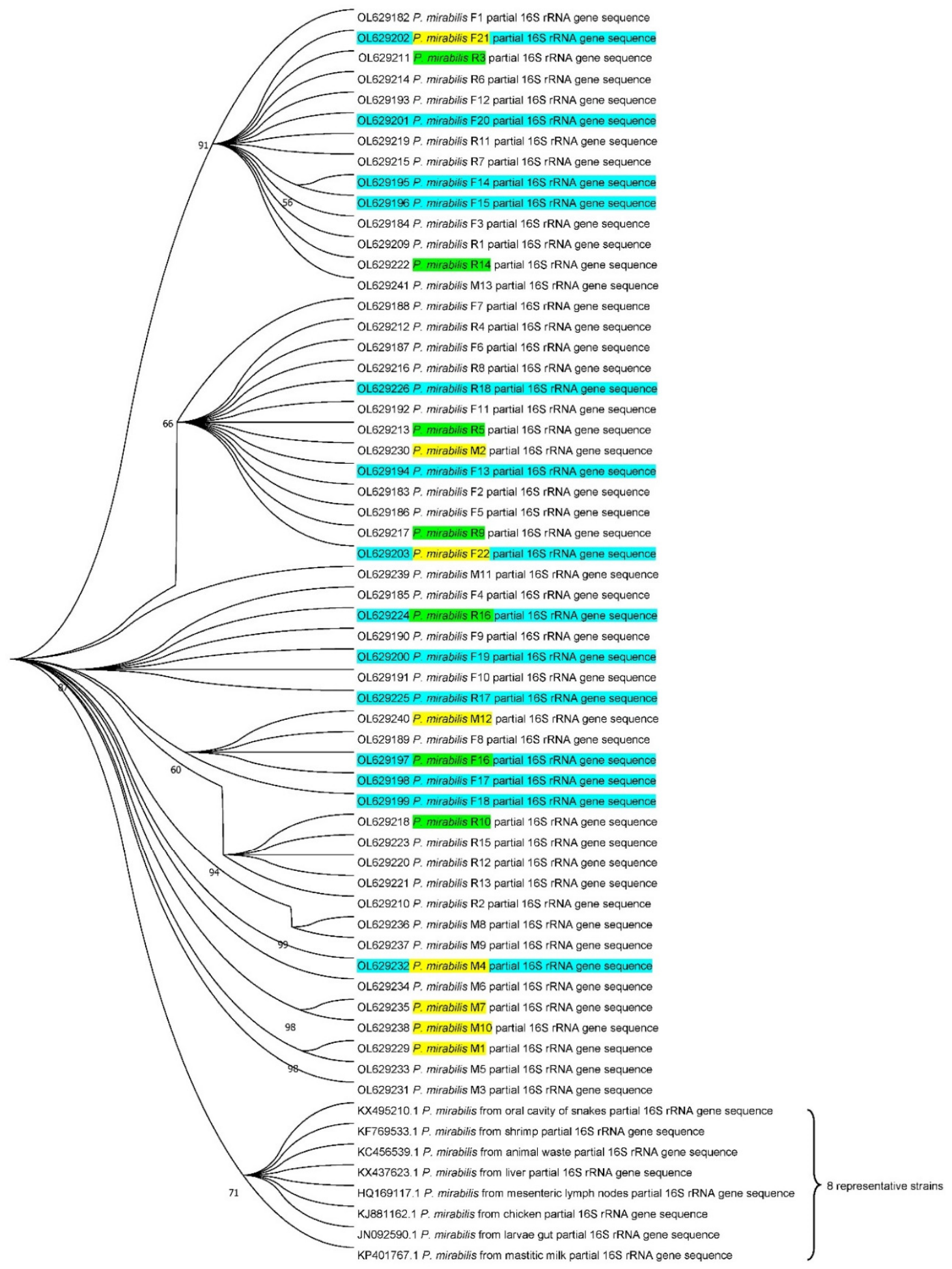

Figure 5. Phylogenetic tree constructed based on $16 \mathrm{~S}$ rRNA sequences of 61 P. mirabilis isolates using the neighbor-joining method. Eight representative isolates from different sources are labeled with big parentheses, 14 isolates from farms environment in the present study are marked in turquoise, and isolates harboring $b l a_{\mathrm{NDM}}$ or $b l a_{\mathrm{OXA}-24}$ are marked in green or yellow, respectively. All sequences were aligned using ClustalW, then the aligned data were evaluated by the neighbor-joining approach using MEGA7 software with 2000 replications of bootstrap. Branches corresponding to partitions reproduced in less than $50 \%$ bootstrap replicates are collapsed. There were a total of 1337 positions in the final dataset. 


\section{Discussion}

Bacterial antibiotic resistance is a global public health threat, and one important cause of it is the multidrug bacterial isolates of animal origins acting as an important source for human infections [46-48]. We investigated the characteristics of 53 P. mirabilis isolates from fox, raccoon and mink farms-the results show that the proportion of MDR isolates among all the P. mirabilis isolates was up to $73.58 \%$, similar to that among the 32 P. mirabilis isolates from chicken carcasses in a poultry slaughterhouse in Brazil (78.13\%) [47]. ESBL production is significantly associated with mortality in patients with bacteremia caused by $P$. mirabilis [49]. In this study, 51 of the 53 P. mirabilis isolates were resistant to betalactam antibiotics and most isolates exhibited two or more beta-lactamase genes. The most common ESBL-encoding gene among the 53 P. mirabilis isolates from foxes, raccoons and minks is $b l a_{\mathrm{TEM}}(83.02 \%)$, which is spread worldwide and is now found in many different species of the order of Enterobacterales [17]. Carbapenem resistance rates are typically extremely low in clinical P. mirabilis isolates; however, approximately $71.70 \%$ of isolates from foxes, raccoons and minks were resistant to imipenem. Among the nine detected carbapenemase genes, the class D carbapenemase gene bla $a_{\mathrm{OXA}-24}(15.09 \%)$ and the class B metallo-beta-lactamase $b l a_{\mathrm{NDM}}(13.21 \%)$ were found for the first time in P. mirabilis isolates from foxes, raccoons and minks. Kang et al. found that $16.67 \%(6 / 54)$ of the P. mirabilis isolates from wild animals were resistant to meropenem, and they mainly carried the carbapenem-resistance genes $b l a_{\mathrm{OXA}-1}$ and $b l a_{\mathrm{NDM}-1}$ [19]. For the 35 P. mirabilis isolates obtained from 240 duck samples in Egypt, only three strains were carbapenem-resistant, two strains harbored the $b l a_{\mathrm{NDM}-1}$ gene, and one strain carried the bla $a_{\mathrm{KPC}}$ gene [21]. The presence of bla $a_{\mathrm{NDM}-1}$ in Proteus spp. clinical isolates is still episodic in China and many other countries [17]. However, the $b l a_{\mathrm{NDM}-1}$ gene had been identified on a genomic island in P. mirabilis recovered from the urine of a hospitalized patient in France in 2012 [50]. The $b a_{\mathrm{OXA}} 24$ gene, mainly detected in Acinetobacter baumannii, were shown to appear in reservoirs including livestock, companion animals, and the environment [17,51]. However, the bla $_{\mathrm{OXA}-24}$ gene is only detected in clinical strains of P. mirabilis in the United States [22]. To the best of our knowledge, $P$. mirabilis isolates harboring $b l a_{\mathrm{OXA}-24}$ were identified for the first time from animal origins. Some other mechanisms including through porin mutation with or without decreased expression of penicillin binding proteins may contribute to the high imipenem-resistance rates of $P$. mirabilis isolates in this study. Moreover, the prevalence of beta-lactam-resistant $P$. mirabilis isolates from fur animals in this study and the similar antibiotic resistance profiling between P. mirabilis isolates from fur animals and farm environment suggested that MDR P. mirabilis isolates may likely spread from fur animals to the environment and potentially humans, posing a public health threat [52].

We also found increasing prevalence and diversity of some other antibiotic resistance genes in P. mirabilis from foxes, raccoons and minks. It was reported that $a a c\left(6^{\prime}\right)-I b-c r$ conferring quinolones and aminoglycosides resistance was common in Escherichia coli [53]. Here we showed that the detection rate of $a a c\left(6^{\prime}\right)-I b-c r$ among 53 P. mirabilis isolates was up to $71.7 \%$, similar to the $63.2 \%$ among 19 P. mirabilis isolates from a Chinese hospital by $\mathrm{Hu}$ et al. [54]. The detection rates of quinolone resistance genes $q n r A(5.66 \%)$ and $q n r B(22.64 \%)$ were higher than the $0 \%$ from chicken carcasses in Brazil by Sanches et al. [19]. For the aminoglycoside resistance of $P$. mirabilis isolates in this study, another frequently encountered resistance gene was aad $A$, which may result in high resistance rates to streptomycin in these P. mirabilis isolates. These results indicate that $a a c\left(6^{\prime}\right)-\mathrm{Ib}-\mathrm{cr}$ and $a a d A$ gene might be common in P. mirabilis isolates in foxes, raccoons and minks of China. Florfenicol is mainly used in veterinary medicine, a key gene for florfenicol and chloramphenicol resistance, floR, coding for an efflux protein of 12 transmembrane segments, can spread among bacteria of the same and different species or genera through horizontal gene transfer [55]. In this study, we found that $90.57 \%$ of $P$. mirabilis isolates were resistant to florfenicol, of which $77.36 \%$ carried the floR gene. So, the emergence and dissemination of florfenicol resistance among P. mirabilis isolates will limit the use of this antimicrobial for treating bacterial infections. 
All $P$. mirabilis isolates harbored ureC, zapA, pmfA, atfA and mrpA virulence genes, which were also prevalent in the $P$. mirabilis isolates from chicken carcasses [47] and pork meat [24]. Among the 10 virulence genes, the detection rate of ucaA, a major fimbrial subunit that can enhance the adhesion of P. mirabilis, was the lowest [56]. However, we showed that the virulence of a $u c a A$-positive strain was about 5 -fold lower than that of a $u c a A$-negative strain in G. mellonella larvae. Moreover, the carriage rate of virulenceassociated genes in these P. mirabilis isolates did not correlate with higher pathogenicity in a G. mellonella model. Three P. mirabilis isolates carrying all detected 10 virulence genes from different animal species showed different lethal abilities in G. mellonella larvae. These P. mirabilis isolates could multiply rapidly in the hemolymph of the larvae, similarly to $S$. Enteritidis, resulting in a fierce but ineffective inflammatory response triggered by high bacterial burdens and hemocyte depletion [57]. These results suggest that the carriage rate of virulence genes in P. mirabilis isolates can only reflect their epidemic, the pathogenicity of bacteria should be evaluated by appropriate animal models.

\section{Conclusions}

In the present study, we firstly reported the emergence of carbapenem-resistant P. mirabilis isolates harboring $b l a_{\mathrm{OXA}-24}(15.09 \%)$ or $b l a_{\mathrm{NDM}}(13.21 \%)$ from foxes, raccoons and minks. All P. mirabilis isolates harbored ureC, zapA, pmfA, atf $A$ and mrpA genes, but the carriage rate of these virulence-associated genes in the isolates did not correlate with higher pathogenicity in a G. mellonella model. Moreover, phylogenetic analysis showed that the P. mirabilis isolates from farm environment samples may have close relatedness with that from animals.

Supplementary Materials: The following are available online at https:/ /www.mdpi.com/article/ 10.3390/biology11020292/s1, Table S1. Characteristics of virulence genes of 53 P. mirabilis isolates from fur animal farms in this study. Table S2. Characteristics of antibiotic resistance genes of $53 \mathrm{P}$. mirabilis isolates from fur animal farms in this study.

Author Contributions: Conceptualization, G.H., G.W. and S.S.; methodology, G.H. and P.L.; investigation, P.L., Y.C. and L.C.; data curation, Y.C.; writing—original draft, P.L.; writing-review and editing, P.L., S.S. and G.H. All authors have read and agreed to the published version of the manuscript.

Funding: This research was funded by Shandong Agricultural Major Application Technology Innovation Project (SD2019XM009) and Shandong Provincial Modern Agricultural Industry Technology System (SDAIT-21-05).

Institutional Review Board Statement: The animal study was reviewed and approved by Animal Care and Use of Shandong Agricultural University (SDAUA-2018-027). Written informed consent was obtained from the owners for the participation of their animals in this study.

Informed Consent Statement: .Not applicable.

Data Availability Statement: The original contributions generated for this study are included in the article, further inquiries can be directed to the corresponding authors.

Acknowledgments: We thank Weixiang Fan for technical support and Yitian Zhou from University of Pennsylvania for English language editing. Also, we thank the anonymous referee for helpful comments and suggestions.

Conflicts of Interest: No conflict of interest exits in the submission of this manuscript, and manuscript is approved by all authors for publication. 


\section{Appendix A}

Table A1. Primer sequence and fragment size of drug resistance genes.

\begin{tabular}{|c|c|c|c|c|}
\hline Name & Gene & Sequence $\left(5^{\prime}-3^{\prime}\right)$ & Size (bp) & Reference \\
\hline \multirow{13}{*}{ Beta-lactams } & $b l a_{\mathrm{TEM}}$ & $\begin{array}{l}\text { F: ATAAAATTCTTGAAGACGAAA } \\
\text { R: GACAGTTACCAATGCTTAATC }\end{array}$ & 643 & [27] \\
\hline & $b l a_{\mathrm{SHV}}$ & F: TTATCTCCCTGTTAGCCACC & 860 & [27] \\
\hline & $b l a_{\mathrm{PSE}}$ & $\begin{array}{l}\text { F: TAGGTGTTTCCGTTCTTG } \\
\text { R: TCATTTCGCTCTTCCATT }\end{array}$ & 150 & [28] \\
\hline & $b l a_{\text {OXA-1 }}$ & $\begin{array}{l}\text { F: TCAACTTTCAAGATCGCA } \\
\text { R: GTGTGTTTAGAATGGTGA }\end{array}$ & 591 & [27] \\
\hline & $b l a_{\mathrm{OXA}-23}$ & $\begin{array}{l}\text { F: GATCGGATTGGAGAACCAGA } \\
\text { R: ATTTCTGACCGCATTTCCAT }\end{array}$ & 501 & {$[30]$} \\
\hline & $b l a_{\mathrm{OXA}-24}$ & $\begin{array}{l}\text { F: TTCCСCTAACATGAATTTGT } \\
\text { R: GTACTAATCAAAGTTGTGAA } \\
\text { R: TGGATTGCACTTCATCTTGG }\end{array}$ & 1024 & {$[30]$} \\
\hline & $b l a_{\mathrm{OXA}-58}$ & $\begin{array}{l}\text { F: TGGCACGCATTTAGACCG } \\
\text { R: AAACCCACATACCAACCC }\end{array}$ & 507 & {$[30]$} \\
\hline & $b l a_{\mathrm{OXA}-48}$ & $\begin{array}{l}\text { F: GCGTGGTTAAGGATGAACAC } \\
\text { R: CATCAAGTTCAACCCAACCG }\end{array}$ & 438 & [29] \\
\hline & $b l a_{\mathrm{CTX}-\mathrm{M}}$ & $\begin{array}{l}\text { F: CGCTTTGCGATGTGCAG } \\
\text { R: ACCGCGATATCGTTGGT }\end{array}$ & 550 & [27] \\
\hline & $b l a_{\mathrm{KPC}}$ & $\begin{array}{c}\text { F: GACGGAAAGCTTACAAAAACTGACA } \\
\text { R: CTTGTCATCCTTGTTAGGCG }\end{array}$ & 259 & {$[31]$} \\
\hline & $b l a_{\mathrm{NDM}}$ & $\begin{array}{l}\text { F: GGTTTGGCGATCTGGTTTTC } \\
\text { R: ATCCAGTTGAGGATCTGGGC }\end{array}$ & 181 & [31] \\
\hline & $b l a_{\mathrm{IMP}}$ & $\begin{array}{l}\text { F: GGAATAGAGTGGCTTAATTCTC } \\
\text { R: CAAGCTTCTATATTTGCGTCACC }\end{array}$ & 275 & {$[31]$} \\
\hline & $b l a_{\mathrm{VIM}}$ & $\begin{array}{c}\text { F: GATGAGTTGCTTTTGATTGATACAGC } \\
\text { R: CGCCCGAAGGACATCAA }\end{array}$ & 153 & [31] \\
\hline \multirow{6}{*}{ Quinolones } & $q n r A$ & $\begin{array}{l}\text { F: ATTTCTCACGCCAGGATTTG } \\
\text { R: GATCGGCAAAGGTCAGGTCA }\end{array}$ & 519 & [27] \\
\hline & $q n r B$ & $\begin{array}{l}\text { F: GATCGTGAAAGCCAGAAAGG } \\
\text { R: ACGATGCCTGGTAGTTGTCC }\end{array}$ & 513 & [27] \\
\hline & qnrC & $\begin{array}{c}\text { F: GGTTGTACATTTATTGAATC } \\
\text { R: TCCACTTTACGAGGTTCT }\end{array}$ & 666 & [27] \\
\hline & $q n r S$ & $\begin{array}{l}\text { F: ACGACATTCGTCAACTGCAA } \\
\text { R: TAAATTGGCACCCTGTAGGC }\end{array}$ & 417 & [27] \\
\hline & $o q x A$ & $\begin{array}{l}\text { F: GATCAGTCAGTGGGATAGTTT } \\
\text { R: TACTCGGCGTTAACTGATTA }\end{array}$ & 670 & [35] \\
\hline & $a a c\left(6^{\prime}\right)-I b-c r$ & $\begin{array}{l}\text { F: TTGCGATGCTCTATGAGTGGCTA } \\
\text { R: CTCGAATGCCTGGCGTGTTT }\end{array}$ & 482 & [27] \\
\hline
\end{tabular}


Table A1. Cont.

\begin{tabular}{|c|c|c|c|c|}
\hline Name & Gene & Sequence $\left(5^{\prime}-3^{\prime}\right)$ & Size (bp) & Reference \\
\hline \multirow{6}{*}{ Aminoglycosides } & $a a C 1$ & $\begin{array}{l}\text { F: ACCTACTCCCAACATCAGCC } \\
\text { R: ATATAGATCTCACTACGCGC }\end{array}$ & 528 & [32] \\
\hline & $a a C 2$ & $\begin{array}{l}\text { F: ACTGTGATGGGATACGCGTC } \\
\text { R: CTCCGTCAGCGTTTCAGCTA }\end{array}$ & 482 & {$[32]$} \\
\hline & $a a C 3$ & $\begin{array}{l}\text { F: CACAAGAACGTGGTCCGCTA } \\
\text { R: AACAGGTAAGCATCCGCATC }\end{array}$ & 185 & {$[32]$} \\
\hline & aadA & $\begin{array}{l}\text { F: GTGGATGGCGGCCTGAAGCC } \\
\text { R: AATGCCCAGTCGGCAGCG }\end{array}$ & 535 & [34] \\
\hline & $a a d B$ & $\begin{array}{l}\text { F: ATGGACACAACGCAGGTC } \\
\text { R: TTAGGCCGCATATCGCGACC }\end{array}$ & 495 & [33] \\
\hline & aphA6 & $\begin{array}{l}\text { F: ATGGAATTGCCCAATATTATTC } \\
\text { R: TCAATTCAATTCATCAAGTTTTA }\end{array}$ & 399 & [33] \\
\hline \multirow{3}{*}{$\begin{array}{l}\text { Folate pathway } \\
\text { antagonists }\end{array}$} & sul1 & $\begin{array}{l}\text { F: CTTCGATGAGAGCCGGCGG C } \\
\text { R: GCAAGGCGGAAACCCGCGCC }\end{array}$ & 238 & [37] \\
\hline & sul2 & $\begin{array}{l}\text { F: CGGCATCGTCAACATAAC C } \\
\text { R: GTGTGCGGATGAAGTCAG }\end{array}$ & 722 & {$[36]$} \\
\hline & sul3 & $\begin{array}{l}\text { F: AGATGTGATTGATTTGGGAGC } \\
\text { R: TAGTTGTTTCTGGATTAGAGCCT }\end{array}$ & 443 & [38] \\
\hline \multirow{2}{*}{ Phenicols } & cmlA & $\begin{array}{l}\text { F: TGTCATTTACGGCATACTCG } \\
\text { R: ATCAGGCATCCCATTCCCAT }\end{array}$ & 900 & [37] \\
\hline & floR & $\begin{array}{l}\text { F: CACGTTGAGCCTCTATATGG } \\
\text { R: ATGCAGAAGTAGAACGCGAC }\end{array}$ & 890 & [27] \\
\hline
\end{tabular}

Table A2. Primers and annealing temperatures of 10 virulence genes.

\begin{tabular}{|c|c|c|c|}
\hline Gene & Sequence $\left(5^{\prime} \rightarrow 3^{\prime}\right)$ & Fragment & Annealing Temperature \\
\hline ureC & $\begin{array}{l}\text { F: GTTATTCGTGATGGGATGGG } \\
\text { R: ATAAAGGTGGTTACGCCAG }\end{array}$ & $375 \mathrm{bp}$ & $52{ }^{\circ} \mathrm{C}$ \\
\hline$m r p A$ & $\begin{array}{l}\text { F: ATTTCAGGAAACAAAAGATG } \\
\text { R: TTCTTACTGATAAGACATTG }\end{array}$ & $410 \mathrm{bp}$ & $39^{\circ} \mathrm{C}$ \\
\hline$z a p A$ & $\begin{array}{l}\text { F: ACCGCAGGAAAACATATAGCCC } \\
\text { R: GCGACTATCTTCCGCATAATCA }\end{array}$ & $493 \mathrm{bp}$ & $52^{\circ} \mathrm{C}$ \\
\hline atf $A$ & $\begin{array}{l}\text { F: CATAATTTCTAGACCTGCCCTAGCA } \\
\text { R: CTGCTTGGATCCGTAATTTTTAACG }\end{array}$ & $365 \mathrm{bp}$ & $49^{\circ} \mathrm{C}$ \\
\hline atfC & $\begin{array}{l}\text { F: AGAAAGGGATCCTACAAATTAA } \\
\text { R: TATAGCATGCATTTAAATTGCC }\end{array}$ & $472 \mathrm{bp}$ & $49^{\circ} \mathrm{C}$ \\
\hline$u c a A$ & $\begin{array}{l}\text { F: GTAAAGTTGTTGCGCAAAC } \\
\text { R: TTGAGCCACTGTGGATACA }\end{array}$ & $365 \mathrm{bp}$ & $49^{\circ} \mathrm{C}$ \\
\hline$p m f A$ & $\begin{array}{l}\text { F: GGATCATCTATAATGAAACTG } \\
\text { R: CTGATAATCAACTTGGAAGTT }\end{array}$ & $534 \mathrm{bp}$ & $52{ }^{\circ} \mathrm{C}$ \\
\hline$r s b A$ & $\begin{array}{l}\text { F: TCGATTTCAGTGTTTGGCCAT } \\
\text { R: TCGATTTCAGTGTTTGGCCAT }\end{array}$ & $1647 \mathrm{bp}$ & $55^{\circ} \mathrm{C}$ \\
\hline $\operatorname{rsm} A$ & $\begin{array}{l}\text { F: TAGCGAGTGTTGACGAGTGG } \\
\text { R: AGCGAGGTGAAGAACGAGAA }\end{array}$ & 562 bp & $56^{\circ} \mathrm{C}$ \\
\hline hmpA & $\begin{array}{l}\text { F: CCAGTGAATTAACGGCAGGT } \\
\text { R: CGTGCCCAGTAATGGCTAAT }\end{array}$ & $654 \mathrm{bp}$ & $55^{\circ} \mathrm{C}$ \\
\hline
\end{tabular}




\section{References}

1. Drzewiecka, D. Significance and roles of Proteus spp. bacteria in natural environments. Microb. Ecol. 2016, 72, 741-758. [CrossRef] [PubMed]

2. Jacobsen, S.; Stickler, D.; Mobley, H.; Shirtliff, M. Complicated catheter-associated urinary tract infections due to Escherichia coli and Proteus mirabilis. Clin. Microbiol. Rev. 2008, 21, 26-59. [CrossRef] [PubMed]

3. Jain, S.; Gaind, R.; Kothari, C.; Sehgal, R.; Shamweel, A.; Thukral, S.S.; Chellani, H.K. VEB-1 extended-spectrum $\beta$-lactamaseproducing multidrug-resistant Proteus mirabilis sepsis outbreak in a neonatal intensive care unit in India: Clinical and diagnostic implications. JMM Case Rep. 2016, 3, e005056. [CrossRef]

4. Cao, B.; Wang, M.; Liu, L.; Zhou, Z.; Wen, S.; Rozalski, A.; Wang, L. 16S-23S rDNA internal transcribed spacer regions in four Proteus species. J. Microbiol. Methods 2009, 77, 109-118. [CrossRef]

5. Wang, Y.; Zhang, S.; Yu, J.; Zhang, H.; Yuan, Z.; Sun, Y.; Zhang, L.; Zhu, Y.; Song, H. An outbreak of Proteus mirabilis food poisoning associated with eating stewed pork balls in brown sauce, Beijing. Food Control 2009, 21, 302305. [CrossRef]

6. $\quad$ Gong, Z.; Shi, X.; Bai, F.; He, X.; Zhang, H.; Li, Y.; Yu, W.; Lin, Y.; Qiu, Y.; Chen, Q.; et al. Characterization of a novel diarrheagenic strain of Proteus mirabilis associated with food poisoning in China. Front. Microbiol. 2019, 10, 2810. [CrossRef]

7. Shi, X.; Lin, Y.; Qiu, Y.; Li, Y.; Jiang, M.; Chen, Q.; Jiang, Y.; Yuan, J.; Cao, H.; Hu, Q.; et al. Comparative screening of digestion tract toxic genes in Proteus mirabilis. PLoS ONE 2016, 11, e0151873. [CrossRef]

8. Pattanayak, S.; Kumar, P.R.; Sahoo, M.K.; Paul, A.; Sahoo, P.K. First field-based evidence of association of Proteus mirabilis causing large scale mortality in Indian major carp farming. Aquaculture 2018, 495, 435-442. [CrossRef]

9. Cabassi, C.S.; Taddei, S.; Predari, G.; Galvani, G.; Ghidini, F.; Schiano, E.; Cavirani, S. Bacteriologic findings in ostrich ( struthio camelus ) eggs from farms with reproductive failures. Avian Dis. 2004, 48, 716-722. [CrossRef]

10. Milagro, F.-D.; Monica, C.; Alexandra, G.-A.M.; Pulchérie, G.; Paula, S. Occurrence of Proteus mirabilis associated with two species of venezuelan oysters. Rev. Do Inst. Med. Trop. Sao Paulo 2007, 49, 355-359.

11. Sun, Y.; Wen, S.; Zhao, L.; Xia, Q.; Wang, H. Association among biofilm formation, virulence gene expression, and antibiotic resistance in Proteus mirabilis isolates from diarrhetic animals in Northeast China. BMC Vet. Res. 2020, 16, 176. [CrossRef] [PubMed]

12. Malayeri, H.Z.; Jamshidi, S.; Salehi, T.Z. Identification and antimicrobial susceptibility patterns of bacteria causing otitis externa in dogs. Vet. Res. Commun. 2010, 34, 435-444. [CrossRef] [PubMed]

13. Papp-Wallace, K.M.; Endimiani, A.; Taracila, M.A.; Bonomo, R.A. Carbapenems: Past, present, and future. Antimicrob. Agents Chemother. 2011, 55, 4943-4960. [CrossRef] [PubMed]

14. Ghafourian, S.; Sadeghifard, N.; Soheili, S.; Sekawi, Z. Extended spectrum beta-lactamases: Definition, classification and epidemiology. Curr. Issues Mol. Biol. 2015, 17, 11-21.

15. Tibbetts, R.; Frye, J.G.; Marschall, J.; Warren, D.; Dunne, W. Detection of KPC-2 in a clinical isolate of Proteus mirabilis and first reported description of carbapenemase resistance caused by a KPC beta-lactamase in P. mirabilis. J. Clin. Microbiol. 2008, 46, 3080-3083. [CrossRef]

16. Cabral, A.B.; Maciel, M.A.; Barros, J.F.; Antunes, M.M.; Lopes, A.C. Detection of bla $a_{\mathrm{KPC}-2}$ in Proteus mirabilis in Brazil. Rev. Soc. Bras. Med. Trop. 2015, 48, 94-95. [CrossRef] [PubMed]

17. Girlich, D.; Bonnin, R.A.; Dortet, L.; Naas, T. Genetics of acquired antibiotic resistance genes in Proteus spp. Front. Microbiol. 2020, 11, 256. [CrossRef]

18. Xie, X.; Zhang, J.; Wang, H.N.; Lei, C.W. Whole genome sequence of a New Delhi metallo-beta-lactamase 1-producing Proteus mirabilis isolate SNYG35 from broiler chicken in China. J. Glob. Antimicrob. Resist. 2021, 24, 266-269. [CrossRef]

19. Kang, Q.; Wang, X.; Zhao, J.; Liu, Z.; Ji, F.; Chang, H.; Yang, J.; Hu, S.; Jia, T.; Wang, X.; et al. Multidrug-resistant Proteus mirabilis isolates carrying bla $a_{\mathrm{OXA}-1}$ and bla $a_{\mathrm{NDM}-1}$ from wildlife in China: Increasing public health risk. Integr. Zool. 2021, 16, 798-809. [CrossRef]

20. Lei, C.W.; Zhang, A.Y.; Liu, B.H.; Wang, H.N.; Yang, L.Q.; Guan, Z.B.; Xu, C.W.; Zhang, D.D.; Yang, Y.Q. Two novel Salmonella genomic island 1 variants in Proteus mirabilis isolates from swine farms in China. Antimicrob. Agents Chemother. 2015, 59, 4336-4338. [CrossRef]

21. Algammal, A.M.; Hashem, H.R.; Alfifi, K.J.; Hetta, H.F.; Sheraba, N.S.; Ramadan, H.; El-Tarabili, R.M. atpD gene sequencing, multidrug resistance traits, virulence-determinants, and antimicrobial resistance genes of emerging XDR and MDR-Proteus mirabilis. Sci. Rep. 2021, 11, 9476. [CrossRef] [PubMed]

22. Leulmi, Z.; Kandouli, C.; Mihoubi, I.; Benlabed, K.; Lezzar, A.; Rolain, J.M. First report of bla OxA-24 carbapenemase gene, armA methyltransferase and $a a c\left(6^{\prime}\right)-I b-c r$ among multidrug-resistant clinical isolates of Proteus mirabilis in Algeria. J. Glob. Antimicrob. Resist 2019, 16, 125-129. [CrossRef] [PubMed]

23. Chen, L.; Al Laham, N.; Chavda, K.D.; Mediavilla, J.R.; Jacobs, M.R.; Bonomo, R.A.; Kreiswirth, B.N. First report of an OXA-48producing multidrug-resistant Proteus mirabilis strain from Gaza, Palestine. Antimicrob. Agents Chemother. 2015, 59, $4305-4307$. [CrossRef] [PubMed]

24. Silva, S.M.; Caroline, R.d.S.; Carvalho, S.L.; Hugo, M.V.; Gabriel, L.B.M.; Henrique, M.G.G.; Henrique, D.d.O.B.; Kenji, N.E.; Carla, F.G.L.; Carolina, V.E.; et al. Proteus mirabilis from community-acquired urinary tract infections (UTI-CA) shares genetic similarity and virulence factors with isolates from chicken, beef and pork meat. Microb. Pathog. 2021, 158, 105098. 
25. Clinical and Laboratory Standards Institute. Performance Standards for Antimicrobial Susceptibility Testing 27th ed CLSI Supplement M100-S27; Clinical and Laboratory Standards Institute: Wayne, PA, USA, 2017.

26. Clinical Laboratory Standards Institute. Performance Standards for Antimicrobial Disk Susceptibility Tests for Bacteria Isolated from Animals: CLSI Supplement VET01S; Replaces VET01-S2; Clinical and Laboratory Standards Institute: Wayne, PA, USA, 2015.

27. Ahmed, A.M.; Yusuke, M.; Maiko, S.; Akito, M.; Hitoshi, W.; Yukio, F.; Tadashi, S. Zoo animals as reservoirs of gram-negative bacteria harboring integrons and antimicrobial resistance genes. Appl. Environ. Microbiol. 2007, 73, 6686-6690. [CrossRef]

28. Puah, S.-M.; Puthucheary, S.D.; Liew, F.-Y.; Chua, K.-H. Aeromonas aquariorum clinical isolates: Antimicrobial profiles, plasmids and genetic determinants. Int. J. Antimicrob. Agents 2013, 41, 281-284. [CrossRef]

29. Poirel, L.; Walsh, T.R.; Cuvillier, V.; Nordmann, P. Multiplex PCR for detection of acquired carbapenemase genes. Diagn. Microbiol. Infect. Dis. 2011, 70, 119-123. [CrossRef]

30. Hou, C.; Yang, F. Drug-resistant gene of blaOXA-23, blaOXA-24, blaOXA-51 and blaOXA-58 in Acinetobacter baumannii. Int. J. Clin. Exp. Med. 2015, 8, 13859-13863.

31. Oliveira, M.; Nunes, M.; Barreto Crespo, M.T.; Silva, A.F. The environmental contribution to the dissemination of carbapenem and (fluoro)quinolone resistance genes by discharged and reused wastewater effluents: The role of cellular and extracellular DNA. Water Res. 2020, 182, 116011. [CrossRef]

32. Navajas-Benito, E.V.; Alonso, C.A.; Sanz, S.; Olarte, C.; Martínez-Olarte, R.; Hidalgo-Sanz, S.; Somalo, S.; Torres, C. Molecular characterization of antibiotic resistance in Escherichia coli strains from a dairy cattle farm and its surroundings. J. Sci. Food Agric. 2017, 97, 362-365. [CrossRef]

33. Sarhaddi, N.; Soleimanpour, S.; Farsiani, H.; Mosavat, A.; Dolatabadi, S.; Salimizand, H.; Jamehdar, S.A. Elevated prevalence of multidrug-resistant Acinetobacter baumannii with extensive genetic diversity in the largest burn centre of northeast Iran. J. Glob. Antimicrob. Resist. 2017, 8, 60-66. [CrossRef] [PubMed]

34. Nguyen, V.C.; Lijun, Z.; Thi, T.T.V.; Hoang, S.H.P.; Tran, N.T.; Qi, H.; Rui, Z. Association between the phenotypes and genotypes of antimicrobial resistance in Haemophilus parasuis isolates from swine in Quang Binh and Thua Thien Hue Provinces, Vietnam Engineering 2020, 6, 40-48. [CrossRef]

35. Ping, L.X.; Jing, X.; Lei, Y.; Liang, L.; Jian, S.; Hong, L.Y.; Xia, J.H. Characterization of CTX-M-14-producing Escherichia coli from food-producing animals. Front. Microbiol. 2015, 6, 1136.

36. Chu, C.; Chiu, C.; Wu, W.; Chu, C.; Liu, T.; Ou, J. Large drug resistance virulence plasmids of clinical isolates of Salmonella enterica serovar Choleraesuis. Antimicrob. Agents Chemother. 2001, 45, 2299-2303. [CrossRef]

37. Guerra, B.; Soto, S.; Argüelles, J.; Mendoza, M. Multidrug resistance is mediated by large plasmids carrying a class 1 integron in the emergent Salmonella enterica serotype [4,5,12:i:-]. Antimicrob. Agents Chemother. 2001, 45, 1305-1308. [CrossRef]

38. Chen, S.; Zhao, S.; White, D.G.; Schroeder, C.M.; Lu, R.; Yang, H.; McDermott, P.F.; Ayers, S.; Meng, J. Characterization of multiple-antimicrobial-resistant salmonella serovars isolated from retail meats. Appl. Environ. Microbiol. 2004, 70, 1-7. [CrossRef]

39. Dashti, A.A.; Jadaon, M.M.; Abdulsamad, A.M.; Dashti, H.M. Heat treatment of bacteria: A simple method of DNA extraction for molecular techniques. Kuwait Med. J. 2009, 41, 117-122.

40. YouQin, Y.; ChunHua, H.; YiLong, C.; Yun, S.; XiaoWei, H.; DeHui, M. Comparative study on pathogenicity in mice and carriage of virulence genes of Proteus mirabilis isolates from various origins. Chin. J. Biol. 2019, 32, 289-294.

41. Hernandez, R.J.; Hesse, E.; Dowling, A.J.; Coyle, N.M.; Feil, E.J.; Gaze, W.H.; Vos, M. Using the wax moth larva Galleria mellonella infection model to detect emerging bacterial pathogens. PeerJ 2019, 6, e6150. [CrossRef]

42. Peleg, O.; Eliopoulos, G.; Moellering, R. Galleria mellonella as a model system to study Acinetobacter baumannii pathogenesis and therapeutics. In Proceedings of the Infectious Diseases Society of America 2008 Annual Meeting, Washington, DC, USA, 25-28 October 2008; pp. 2605-2609.

43. Finney, D.J. The median lethal dose and its estimation. Arch. Toxicol. 1985, 56, 215-218. [CrossRef]

44. Yang, B.; Wang, Y.; Qian, P.Y. Sensitivity and correlation of hypervariable regions in 16S rRNA genes in phylogenetic analysis. BMC Bioinform. 2016, 17, 135. [CrossRef] [PubMed]

45. Kumar, S.; Stecher, G.; Tamura, K. MEGA7: Molecular evolutionary genetics analysis version 7.0 for bigger datasets. Mol. Biol. Evol. 2016, 33, 1870-1874. [CrossRef] [PubMed]

46. Van Boeckel, T.P.; Brower, C.; Gilbert, M.; Grenfell, B.T.; Levin, S.A.; Robinson, T.P.; Teillant, A.; Laxminarayan, R. Global trends in antimicrobial use in food animals. Proc. Natl. Acad. Sci. USA 2015, 112, 5649-5654. [CrossRef] [PubMed]

47. Sanches, M.S.; Baptista, A.A.; de Souza, M.; Menck-Costa, M.F.; Koga, V.L.; Kobayashi, R.K.; Rocha, S.P. Genotypic and phenotypic profiles of virulence factors and antimicrobial resistance of Proteus mirabilis isolated from chicken carcasses: Potential zoonotic risk. Braz. J. Microbiol. 2019, 50, 685-694. [CrossRef] [PubMed]

48. Thi, N.N.; Niwat, C.; J, C.-M.J. Antimicrobial resistance in bacterial poultry pathogens: A review. Front. Vet. Sci. 2017, 4, 126.

49. Ahn, J.Y.; Ann, H.W.; Jeon, Y.; Ahn, M.Y.; Oh, D.H.; Kim, Y.C.; Kim, E.J.; Song, J.E.; Jung, I.Y.; Kim, M.H.; et al. The impact of production of extended-spectrum beta-lactamases on the 28-day mortality rate of patients with Proteus mirabilis bacteremia in Korea. BMC Infect. Dis. 2017, 17, 327. [CrossRef]

50. Girlich, D.; Dortet, L.; Poirel, L.; Nordmann, P. Integration of the bla $a_{\mathrm{NDM}-1}$ carbapenemase gene into Proteus genomic island 1 (PGI1-PmPEL) in a Proteus mirabilis clinical isolate. J. Antimicrob. Chemother. 2015, 70, 98-102. [CrossRef]

51. Hammoudi Halat, D.; Ayoub Moubareck, C. The current burden of carbapenemases: Review of significant properties and dissemination among Gram-negative bacteria. Antibiotics 2020, 9, 186. [CrossRef] 
52. Sofia, M.; George, S.; Karageorgopoulos, D.E.; Mavros, M.N.; Diamantis, K.; Falagas, M.E. In vitro antimicrobial susceptibility to isepamicin of 6,296 Enterobacteriaceae clinical isolates collected at a tertiary care university hospital in Greece. Antimicrob. Agents Chemother. 2012, 56, 3067-3073.

53. Pasom, W.; Chanawong, A.; Lulitanond, A.; Wilailuckana, C.; Kenprom, S.; Puang-Ngern, P. Plasmid-mediated quinolone resistance genes, $a a c\left(6^{\prime}\right)-I b-c r, q n r S, q n r B$, and $q n r A$, in urinary isolates of Escherichia coli and Klebsiella pneumoniae at a teaching hospital, Thailand. Jpn. J. Infect. Dis. 2013, 66, 428-432. [CrossRef]

54. Hu, Y.; Cai, J.; Zhang, R.; Zhou, H.; Sun, Q.; Chen, G. Emergence of Proteus mirabilis harboring bla $\mathrm{KPC}_{2}$ and qnrD in a Chinese Hospital. Antimicrob. Agents Chemother. 2012, 56, 2278-2282. [CrossRef] [PubMed]

55. Lu, J.; Zhang, J.; Xu, L.; Liu, Y.; Li, P.; Zhu, T.; Cheng, C.; Lu, S.; Xu, T.; Yi, H.; et al. Spread of the florfenicol resistance floR gene among clinical Klebsiella pneumoniae isolates in China. Antimicrob. Resist. Infect. Control. 2018, 7, 127. [CrossRef] [PubMed]

56. Pellegrino, R.; Scavone, P.; Umpiérrez, A.; Maskell, D.J.; Zunino, P. Proteus mirabilis uroepithelial cell adhesin (UCA) fimbria plays a role in the colonization of the urinary tract. Pathog. Dis. 2013, 67, 104-107. [CrossRef] [PubMed]

57. Insua, J.L.; Llobet, E.; Moranta, D.; Pérez-Gutiérrez, C.; Tomás, A.; Garmendia, J.; Bengoechea, J.A. Modeling Klebsiella pneumoniae pathogenesis by infection of the wax moth Galleria mellonella. Infect. Immun. 2013, 81, 3552-3565. [CrossRef] 